RECEIVED:

30 May 2020

ACCEPTED:

30 June 2020

RELEASED:

20 July 2020
UDC 658.5 : 377.1

DOI 10.26661/2522-1566/2020-2/12-01

\title{
TRAINER EXPERTISE IN BUSINESS TRAINING: EVIDENCE FROM THE SRI LANKAN MICROFINANCE INSTITUTIONS
}

\author{
Ruwan Abeysekera \\ University of Kelaniya, Sri Lanka \\ ORCID ID: 0000-0002-2858-6483
}

\section{Authoremail: ruwanab@kln.ac.lk}

\begin{abstract}
Microfinance Institutions (MFIs) provide business training to its clients in order to improve their knowledge and skills so that they can manage their businesses effectively and efficiently. MFIs can also experience better loan repayment rates due to the provision of business training. Thus, business training is important to both MFIs and clients. To deliver business training successfully, the expertise of the trainers matters significantly. Hence, the objectives of this study are to define the expertise, to identify how expertise could help clients in their business ventures, and to identify strategies used by trainers to transfer their expertise. The case study method was used to carry out this study and six Sri Lankan MFIs were used as cases. One manager, one trainer, and one owner manager/client from each MFI were selected for interviews and hence, 18 in depth interviews were conducted to gather data. The findings reveal that the trainers' expertise consists of business knowledge and experiential knowledge. Trainers use business knowledge to provide subject knowledge such as financial literacy and business plan preparation. Experiential knowledge is used to create networking opportunities and to provide subject knowledge as well. Further, the trainers use strategies such as interactive training and communication to transfer the expertise. The findings of this study would be useful to microfinance practitioners, policy makers, and it further contributes to the knowledge domain of microfinance.
\end{abstract}

Key words: business training, microfinance, trainers, expertise, microenterprise. JEL Classification: M10.

\section{INTRODUCTION}

Microfinance refers to the provision of small unsecured loans, business development services (BDS), insurance and savings products to individuals and groups to start and expand businesses Khavul, 2010; ADB, 1997). The main objectives of microfinance are poverty alleviation, development of entrepreneurs and women empowerment. Microfinance Institutions (MFIs) provide microfinance to individuals with low income (Khavul, 2010; ADB, 1997). Thus, they cater to 2.8 billion people living on less than $\$ 2$ a day in developing countries (World Bank, 2014; Easterly, 2006, p. 165). However, MFIs operate in developed countries as well in the context of helping micro entrepreneurs. MFIs use innovative techniques such as group liability, gradually increasing loan sizes, and pre-loan savings requirements to cater to its clientele (CGAP, 2011; Khavul, 2010; ADB, 1997). Sri Lanka has an established microfinance sector, the roots of which can be traced 
Abeysekera, R. (2020), "Trainer expertise in business training: evidence from the Sri Lankan Microfinance Institutions", Management and entrepreneurship: trends of development, Vol. 2, Issue 12, pp. 8-21, available at: https://doi.org/10.26661/2522-1566/2020-2/12-01

back to 1900s. There are government MFIs, bank MFIs, NGO MFIs, and cooperative MFIs operating in Sri Lanka. (GTZProMis, 2010; Tilakaratne et al., 2005). The microfinance players in Sri Lanka cover the whole country and the Sri Lankan government is keen to develop the microfinance sector due its contribution to the economy (GTZProMis, 2010; Tilakaratne et al., 2005).

Microfinance Institutions (MFIs) provide business training under BDS to its clients in addition to the provision of credit. BDS are non-financial services offered to entrepreneurs by MFIs, such as management training, vocational training skills, marketing assistance, and access to technology (Khavul, 2010; Sievers and Vandenberg, 2007). MFIs use either internal, or external trainers, or both to provide business training. Business training covers areas including that of financial literacy, business idea generation, marketing, record keeping, inventory management (Abeysekera, 2016; ADEMCOL, 2001). The literature indicates that clients would improve their knowledge and skills owing to the business training given, thereby resulting in better business performance in terms of profits and sales. MFIs could also reap benefits due to the provision of business training as they could experience higher loan repayment rates. This is because clients would be able to better manage their finances due to the business training obtained and thus, could repay the loan obtained from MFIs. Apart from higher loan repayments, MFIs could also experience fewer client dropouts, higher outreach potential, and increased employee motivation due to the provision of business training (ADEMCOL, 2001; Karlan and Valdivia; 2006; ILO, 2002). Thus, business training provides benefits to both MFIs and its clients. The expertise of the trainers is paramount to successful training intervention (ADEMCOL, 2001; De wildt, 2004; Tilakaratne et al, 2009). The trainers must have good knowledge and experience in order to deliver business training. Studies show that trainers' expertise could be identified in terms of their qualifications such as degrees and diplomas and experience (ADEMCOL, 2001; De wildt, 2004; Tilakaratne et al, 2009). However the extant literature on microfinance (ADEMCOL, 2001; De wildt, 2004; Tilakaratne et al, 2009) has not defined the expertise of the trainers properly. Further, it has not shown how different components of expertise could help clients. Moreover, there is a dearth of studies conducted on how trainers transfer the expertise in microfinance.

\section{LITERATURE REVIEW}

\section{Business Training in microfinance settings}

In this study, training refers to the provision of training programmes by MFIs on financial literacy and business training, and the follow up support given to owner managers to solve practical problems, provision of tailor-made and specific to the microenterprise (ADEMCOL, 2001; Gibb, 1997; Manpower Services Commission, 1975). Trainers of MFIs provide a number of training programmes to its clients which include financial literacy training, business start-up advice, business idea generation, preparation of business plans, accounting, marketing, inventory control, costing, pricing, sales forecasting and quality of product, training specific to their industries, strategies to access new markets, negotiating new contracts and networking (Abeysekera, 2016; Karlan and Valdivia, 2006). MFI trainers use training approaches, such as interactive training and adult training techniques to provide support to owner managers. The expertise of the trainers and how they transfer the training are key to an effective training intervention.

\section{Expertise and Trainer expertise}

The extant literature shows that there is no consensus on expertise (Huber, 1999). The scholars ascribe different meanings to it. From the viewpoint of psychology, expertise is an intrinsic characteristic exemplified in terms of special knowledge or capability, whereas from a sociological perspective, it considered as a special qualification and status that does not depend on the individual differences (Agnew et al., 1997; Sié and Yakhlef, 2009). Expertise is composed of two components: explicit knowledge of a domain and tacit knowledge of a field (Agnew et al., 1997; Sié and 
Yakhlef, 2009). Explicit knowledge is gained through the qualifications, whereas tacit knowledge is gained through experience/practice. The previous literature on microfinance identifies the expertise of trainers in terms of their qualifications and experience that enhances the business training intervention (ADEMCOL, 2001; TJP, 2003). A study made on an MFI in Columbia reveals that the expertise of the trainers improved the effectiveness of business training (ADEMCOL, 2001). This MFI got qualified and experienced officers with business business/economics degrees to deliver training. These trainers were given training by the MFI on content and adult education techniques. Further, they had to take part in business seminars to advance their knowledge. A study done by TJP (2003) reveals that an MFI in Morocco was unable to deliver the training effectively as its trainers did not have the expertise. A study done by Tilakaratne et al. (2009) on BDS in Sri Lanka found that lack of qualified internal trainers poses a significant problem for MFIs to deliver training programmes. Thus, the literature highlights the importance of expertise of trainers in providing microfinance related services.

\section{Transferring expertise}

While it is important for the trainers to possess the expertise, it is also necessary to transfer (i.e. knowledge transfer) it to the recipients. The literature on knowledge management asserts that knowledge transfer consists of the nature of the knowledge, characteristics of the source and the recipient, the relationship between them, and the organisational context (Argote et al., 2003). The literature on training shows that it is important to identify learner characteristics, intervention design and category, work environment, evaluation, and trainer characteristics in training transfer (Baldwin and Ford, 1988; Hutchins, 2009). Further, it was revealed that tacit knowledge is challenging to transfer compared to explicit knowledge (Nonaka, 1991). Studies conducted on microfinance show that trainers use a number of strategies to transfer the knowledge to the clients. Nieman (2001) asserts that trainers of small businesses should be competent in more than one language when they have to provide training for entrepreneurs who speak more than one language. Karalan and Valdivia's (2006) study in Peru indicates that some trainers had to conduct business training in indigenous languages. Studies made on microfinance reveal that trainers use visual illustrations, participatory exercises that build on clients' experiences and real-life examples of clients in training modules. (ADEMCOL, 2001; Karlan and Valdivia, 2006). Karalan and Valdivia (2006) and TJP (2003) show that they use training videos mostly to educate illiterate clients.

According to literature on small businesses (Accion, 2005; Walker et al; 2007), interactive learning is useful for micro enterprises as it guarantees a high level of learning over short periods of time for owner managers with low formal education. In an interactive training, there is an interaction between the trainer and the trainee in the classroom where the trainee provides his knowledge and experience by connecting with the information and experiences provided by the trainer. Interactive training does not take place in traditional lecture-based environment where passive learning takes place, but in an environment where deep learning emerges through participatory workshops (Accion, 2005; Walker et al; 2007). Trainers use adults learning concepts when providing business training to owner managers. These adult learning concepts depend on the following premises; that adults learn new things in relation to what they already know; that they would like to know new things that can be implemented in short and medium term, as opposed to in the long term; that the message transmitted in the training is not distant to the trainee (for example, trainees in the micro finance sector should not be taught accounting relating to large firms but instead of record keeping techniques relevant to micro enterprises); and finally, that trainees should be destabilised in their learning wherein the trainers should incite doubt and curiosity in the minds of the trainees regarding their prior knowledge in order to enhance their knowledge and learn new things (Accion, 2005).

Though the extant microfinance literature on training discusses expertise and training transfer, it has not defined the expertise in relation to how it helps different areas in business. Further, there 
Abeysekera, R. (2020), "Trainer expertise in business training: evidence from the Sri Lankan Microfinance Institutions", Management and entrepreneurship: trends of development, Vol. 2, Issue 12, pp. 8-21, available at: https://doi.org/10.26661/2522-1566/2020-2/12-01

is a dearth of studies made relation to transfer of expertise. Thus, this study aims to fill these gaps by undertaking this study.

\section{PAPER OBJECTIVE}

In order to address these knowledge gaps, the study aims to explore the expertise of the trainers in the microfinance sector. On the basis of this aim the following objectives were established.

Objective 1) to define the trainer expertise Objective 2) to identify how trainer expertise could help clients in their business ventures, and objective 3 ) to identify strategies used by trainers to transfer their expertise.

To achieve the aim and objectives of the study, the following research questions were developed after reviewing the literature and following the research methodology adopted for the study (i.e. case study).

Question 1) how is the trainer expertise defined? Question 2) how do trainers help the owner managers through the expertise? 3) How do trainers use skills to transfer the expertise to the trainees?

\section{METHODOLOGY}

The expertise of business trainers in microfinance is a contemporary phenomenon and it has not been explored in depth by the researchers. Thus, the case study method is a suitable research strategy to conduct this study. Further, this study uses the multiple case study method which improves the theoretical generalisation compared to statistical generalisation. Six cases (i.e. MFIs) were selected for this study and the selection of six cases was in line with Eisenhard's (1989) proposition of 4-6 cases for a multiple case study method. Cases (i.e. MFIs) and respondents were chosen for the study by using the purposive sampling technique. Six cases were selected based on the MFI type (i.e. government, bank, NGO, cooperative) and making sure they provided business training. Manager, trainer, and one owner manager/client from each MFI were chosen for the study. The unit of analysis for this study was individuals as listed above.

The details of the MFIs chosen for the study are given below in the Table 1.

Table 1

Types of MFIs chosen for the study

\begin{tabular}{ll}
\hline MFIs & Type of MFI \\
\hline MFI-1 & Public company \\
\hline MFI-2 & Non-Bank \\
\hline MFI-3 & Private Bank \\
\hline MFI-4 & Government Non-Bank \\
\hline MFI-5 & NGO \\
\hline MFI-6 & Government \\
\hline
\end{tabular}

Source: Compiled by the author 
A pilot study was conducted before the data collection began in order to refine the semistructured questionnaire that was used to collect the data. Therein, 18 in -depth interviews (i.e. three interviews from each case) were conducted and each interview took about 45 - 60 minutes. All the interviews were tape-recorded and then transcribed. For ethical reasons, informed consent was obtained from each respondent.

The data were analysed using thematic analysis which was carried out based on the main research questions. Construct validity was achieved by using multiple data sources such as interview data, observations, and company records. Internal validity, which looks for causal relationships was met by using pattern matching in the data analysis. Since the study was a multiple case study, the findings could be generalised to a certain extent, even though the main objective of a qualitative study is theoretical generalisation as opposed to statistical generalisation. Thus, external validity could be achieved as the multiple case study method looks at generalisation of findings to domains (Yin, 2009). Reliability suggests as to whether the operations of the study such as data collection could be repeated with the same results. In this study, the case study protocol was used so that same results could be obtained by repeating the study again (Yin, 2009).

\section{RESULTS AND DISCUSSION}

\section{Findings}

The findings of this study are summarised in the table below.

Findings of the study

\begin{tabular}{cc}
\hline Research Question & Findings \\
\hline How is the trainer expertise defined? & $\begin{array}{c}\text { Business knowledge gained through } \\
\text { qualifications and experiential knowledge } \\
\text { gained through working with owner managers } \\
\text { and own businesses. }\end{array}$ \\
$\begin{array}{c}\text { How do trainers help the owner managers } \\
\text { through the expertise? }\end{array}$ & $\begin{array}{c}\text { Trainers use business knowledge to train owner } \\
\text { managers in the areas of financial literacy, } \\
\text { business plan preparation etc. They use } \\
\text { experiential knowledge to impart subject } \\
\text { knowledge and create networking opportunities. }\end{array}$ \\
How do trainers use skills to transfer the \\
expertise to the trainees? & $\begin{array}{c}\text { Trainers use communication skills such as non- } \\
\text { technical communication, knowledge of } \\
\text { different languages, and interactive training to } \\
\text { transfer expertise. }\end{array}$ \\
\hline
\end{tabular}

Source: compiled by the author

The findings are presented below under the each research question. 
Abeysekera, R. (2020), "Trainer expertise in business training: evidence from the Sri Lankan Microfinance Institutions", Management and entrepreneurship: trends of development, Vol. 2, Issue 12, pp. 8-21, available at: https://doi.org/10.26661/2522-1566/2020-2/12-01

\section{Question no 1: How is trainer expertise defined?}

The findings show that trainer's expertise refers to the business knowledge and experiential knowledge. The business knowledge of a trainer refers to the knowledge gained through the qualifications such as degrees/diplomas in business and undergoing Training of Trainers (TOT) programmes. Experiential knowledge refers to the knowledge gained through working with owner managers and own businesses.

The following quotations highlight how the trainers acquired business knowledge.

Enterprise Development Services Manager MFI-1 stated:

"When recruiting trainers, we look at their qualifications. We expect them to have a degree/diploma in business. We always send our trainers for Training of Trainers (TOT) programmes. We do not have a full time team of trainers. So we send selected branch managers and regional managers for these trainings. We provide training for our clients in the areas of financial literacy, business plan preparation, record keeping, marketing, costing, purchasing and inventory management. In addition, we provide training in communication and leadership as well"

The trainer of MFI-2 stated:

"Number of Training of Trainers (TOTs) undergone, educational qualifications in Business are important for a trainer. I am a Master trainer. I have participated in many TOT programmes. I have followed "Start and Improve Your Business (SIYB)", world renowned ILO certified business training programmes (TOT). Under which I learnt how to train the clients in the areas such as business plan preparation, record keeping, marketing, costing etc. It is difficult to follow these TOT programmes if you do not have a formal education in business. So formal education in Business and TOT are both important for business knowledge"

The following excerpt shows how the trainer acquires experiential knowledge in training.

The trainer of MFI-2 expressed:

"I have visited many business places and discussed business matters with clients. Moreover, I have come across many real life examples in the classroom when conducting training programmes. So I use this experience in the classroom when giving examples. We have some trainers who have their own businesses. I run a training firm so I know how to run a business. So always could relate my experience in the business in training"

\section{Question 2: How do trainers use expertise to help owner managers?}

The following quotation shows how the trainers help owner managers in areas, such as financial literacy, business plan preparation, record keeping, marketing, costing, purchasing, and inventory management. They imparted subject knowledge which was gained through the business knowledge they possess.

The trainer of MFI-1 stated:

"We provide training for our clients in the areas of financial literacy, business plan preparation, record keeping, marketing, costing, purchasing and inventory management. In addition, we provide training in communication and leadership as well. The business knowledge we have acquired from our qualifications and training undergone help provide these trainings"

The findings show that trainers' experiential knowledge gained through working with clients (trainees) could be used to transfer subject knowledge effectively and create networking opportunities.

The trainer of MFI-4 commented on how he used his experience in providing subject knowledge (e.g. costing, financial literacy) to trainees:

"When we conduct training sessions, we come across examples. For example, in one of my training programmes on costing, I found one trainee, in her garment business selling a blouse for Rs. 250. But when calculated the cost for blouse it was Rs. 252. So the trainee realized there was no point of doing the business. In another example, a trainee was selling ginger sweet, but taking 
money from informal lender for a big interest resulting in a loss. So we pointed out that he should take loan from a bank for a less interest rate. So whenever I conduct training sessions, I highlight these real life examples so that trainees grasp the knowledge easily"

The trainer of MFI-5 explained how he used his experience in providing networking opportunities in training.

"In my training, I allow the trainees to network with each other. For example, in the classroom, there could be a client having a grocery and another client who produces yoghurt. So that yogurt client could sell his products to the grocery client. Further, I always give contact details of the Export Board and other buying agencies for the clients so that they can sell their products"

The owner managers interviewed were of the view that trainers need to possess good expertise in terms of business knowledge and experience.

Owner manager of MFI-6 stated:

"I have attended a number of business training programmes. The trainers were knowledgeable and experienced. I learnt how to maintain an inventory, marketing from the trainers. As you can see after the training, I implemented an inventory management system using the 5 S techniques. Now I can trace spare parts easily without wasting time. Further, I can maintain a minimum inventory which saves money. Further, due to the training I maintain a database of clients so that I can maintain good relationships with clients by sending them greeting cards and reminding our services"

Owner manager of MFI-1 expressed:

"I underwent a SIYB training conducted by the MFI. I attended 4 modules covering marketing, record keeping, accounting and costing. I learnt a lot from this training and as a result, I keep records now by myself. Earlier we used to hire a person for this. Further, when I was applying for a loan from a bank my business training and my record keeping helped me obtain the loan. The trainer who conducted this training was knowledgeable and experienced"

\section{Question 3: How do trainers transfer the expertise to the trainees?}

The findings show that the trainers need to know a number of skills to transfer the expertise to trainees. Unless they have the delivery skills they cannot transfer the expertise to the audience. Communication and interactive training were found to be important in transferring expertise to the owner managers.

Under communication the following sub themes of non-technical communication, motivational communication, languages used, and communication tools emerged.

Non-technical communication

The responses from all the trainers interviewed held the same view that the trainer should communicate clearly without using technical language (i.e. right level of language). Given the background of the owner managers (i.e. low formal education) trainer should not use jargon in training.

Enterprise Services Manager of MFI-2 expressed:

"We always hire trainers who can work with the community (i.e. who can speak the village language). Thus, university lecturers may not be appropriate as they use technical terms in training"

The trainer of MFI-6 stated:

"We do not use technical language in training programmes. Even if want to use them, we try to use them in a simple way. For example, debit /credit words are often used in accounting training conducted for the corporate sector. But for the micro finance sector, suitable simple words like "income and expenses" should be used instead of debit and credit"

The owner manager of MFI-1 expressed: 
Abeysekera, R. (2020), "Trainer expertise in business training: evidence from the Sri Lankan Microfinance Institutions", Management and entrepreneurship: trends of development, Vol. 2, Issue 12, pp. 8-21, available at: https://doi.org/10.26661/2522-1566/2020-2/12-01 him”

"Trainer needs to be able to communicate using simple words so that we can understand

\section{Motivational communication}

The findings from all six MFIs further showed that motivational communication of the trainer where the trainer made use of motivational strategies, was very important to retain the trainees in the classroom. In fact, the internal trainers of MFI-2 and the external trainer emphasised that motivational communication was more important than any other factors in training.

The trainer in micro finance setting is faced with several challenges when dealing with micro finance clients. For example, these clients are adults and often do not like to come to a classroom to learn and would like to learn from informal sources (i.e. friends, peers). Further, these clients do not have time for training as they are busy with their business and household activities. Hence, the trainer needs to be able to motivate the clients to retain them in the classroom by using motivational communication.

The trainer of MFI-2 expressed:

"In general, people do not like to attend training. It is our challenge to retain them. Besides, some clients are compelled to come since they have been asked by the lending institution. Some clients do come just to see whether the training is good. For example, one client from Matara (South of the country), owner of a salon who attended one of business training said that he attended the training only for one hour and ended up attending all five days. It is the skill of the trainer to retain the trainees. So we use communication methods to motivate them"

The owner manager of MFI-4 indicated:

"Trainer should be able to keep us in the classroom by motivating us"

The owner manager of MFI-3 added.

"Recognition and praises are very important in a training session. Those things motivate us to attend training"

Languages used

The findings also revealed that right language (i.e. Sinhalese, Tamil) is important in training which enhances clarity of task of the trainees.

The trainer of MFI-6 emphasised the importance of using languages effectively in the classroom

The trainer of MFI-6 stated:

"For training sometimes we have Tamil speaking attendees. So while we are using Sinhalese as language for the majority, we as trainers need to be able to provide instructions in Tamil also. If the trainer is not conversant in Tamil, then he needs to get somebody's help"

Communication tools

The findings show that trainers need to use special communication tools to clients who are illiterate in order to get them to divulge information and engage in communication. The findings show that trainers need to use the whiteboard for illiterate clients.

The trainer of MFI-2 expressed:

"In the classroom, we find clients who cannot read and write. So I then use the magi board effectively and use numbers and pictures to explain things to them. I have explained Business plan to these clients by using the board effectively"

The findings show that clients (trainees) are reluctant to communicate in the classroom as the training is done for a group of clients. However the trainers put effort to make them talk, by grouping them and giving individual attention.

The trainer of MFI-4 expressed:

"When we are providing record keeping training we select small groups (ex. 10-15). Then we can give one on one attention to trainees. Further, through group activities we have seen them talking" 


\section{Interactive training}

The findings show that interactive training techniques used by the trainers in the classroom allow the trainers and the trainees to interact. The trainers used interactive role playing, problem solving, games and discussions that incorporate the life experiences of the participants. Interactive training improves the self-efficacy of owner managers to practice what is learnt. It was found that participatory workshops were more effective for owner managers than traditional lecture-based courses. The following are some selected quotations to demonstrate interactive training affects coproduction.

The trainer of MFI-2 expressed:

"We use adult learning techniques in the classroom. We always make training simple. We create an environment in which the trainer can interact with trainees in the classroom while trainees can interact with other trainees through activities. For example, to teach how making use of resources efficiently, we introduce a game to trainees in which we ask the trainees to make a ring from a sheet of paper to put around an elephant's neck. This is learning by doing and through experiences. In this process, owner managers first do it, then analyse it in the classroom and try to generalize it so that they can apply the knowledge and skills gained to their businesses. Interactive training is an effective training method"

The trainer of MFI-5 stated how they used group activities in training:

"We train them through group activities. Even financial literacy, we teach through group activities. It really works and the clients like it. In group activities, trainers can work closely with trainees. We used games also for training. But it did not work for our clients. They could not understand it properly."

Owner managers interviewed across cases agreed that interactive training sessions really helped them learn.

The owner manager of MFI-2 stated:

"Trainers used a lot of games, interactive sessions. It was fun and the things we learnt were practical and we can apply in our businesses. During the sessions we were able to interact with the trainer and other trainees"

The interactive training techniques may improve deep learning as opposed to surface learning in traditional lecture-based learning. Further, findings also shed light on the effectiveness of techniques being used for different client segments. For example, games may not work for certain clients' segments. This could be due to the client segment's demographic profiles (ex. education, socio-cultural background).

The findings reveal that the expertise of the trainers may vary, based on the type of trainers that they use i.e. either internal or external trainers, and whether they employ full time/part time, client trainers, which is to a greater extent determined by the type of MFI itself (i.e. public, nonbank, bank, NGO) as chosen for the study. All the MFIs selected for this study used internal and external trainers. External trainers were used when internal trainers did not have the expertise. The findings also reveal that the clients prefer internal trainers over external trainers as they are familiar with internal trainers. In addition, it was found that MFI-1 which was a public company used internal trainers dedicated only to training and they had a training department. These trainers are highly competent and possess speacialised expertise compared to trainers of other MFIs. In contrast, MFI-2, MF-3 and MFI-4 did not have full time dedicated trainers and they used their employees (i.e. managers, counsellors) as trainers by giving them training. MFI-5 and MFI-6 (i.e. government and NGO) used their clients as trainers. However, it was found that these client trainers were not as competent as trainers of other MFIs. Thus, MFIs need to think about maintaining a competent internal staff and should pay attention to whether they employ fulltime/part time or client trainers. 
Abeysekera, R. (2020), "Trainer expertise in business training: evidence from the Sri Lankan Microfinance Institutions", Management and entrepreneurship: trends of development, Vol. 2, Issue 12, pp. 8-21, available at: https://doi.org/10.26661/2522-1566/2020-2/12-01

\section{Discussion, Implications and Concluding Remarks}

The findings show that trainer expertise in microfinance setting can be defined in terms of business knowledge and experiential knowledge. Trainers gain business knowledge through formal qualifications such as business degrees and diplomas and following training of trainers (TOT) programmes. Trainers absorb experiential knowledge by working with clients/owner managers and doing their own businesses. Trainers use business knowledge to impart subject knowledge in areas including financial literacy, business plan preparation, costing; whereas experiential knowledge is used to disseminate subject knowledge and create networking opportunities.

The findings also show that expertise of the trainers may vary based on the MFI. For example, MFI-1 with full time trainers had more expertise compared to trainers in other chosen MFIs. Further, the client trainers used by MFI-5 and MFI-6 did not have sufficient expertise. This is evident as they are not professional trainers.

The extant literature on microfinance has not defined the expertise properly nor has it identified the components of expertise which support different business areas (ADEMCOL, 2001; De Wildt, 2004; Tilakaratne et al, 2009). Hence, the findings of this study are novel. The findings also reveal that trainers need to have different skills to transfer the expertise. It was found that the trainers need to use communication effectively. Use of non-technical communication, motivational communication, knowledge of languages, and communication tools are important to disseminate the expertise. Interactive training is an important technique used by the trainers to impart deep learning.

The findings relating to trainers' transfer skills are in agreement with the literature of small businesses, co-production, and marketing domains. Gibb's (1990) study on small businesses show that non-technical communication of trainers improves training in small business sector. Zorn and Ruccio (1998) highlight the importance of motivational communication between the sales managers and sales teams. Thus, it can be inferred that trainers also need motivational communication. However, literature on small businesses is silent on motivational communication. Nieman (2001) and Karlan and Valdivia (2006), claim that small business trainers should be competent in more than one language. ADEMCOL (2001), Karlan and Valdivia (2006), ACCION (2005) and TJP (2003), show that trainers need to use communication tools, interactive training and adult training techniques such as visual illustrations, training videos, and participatory workshops to communicate effectively with adult clients that are often illiterate.

\section{CONCLUSION}

The findings of this study can be used by the practitioners and policy makers of microfinance to improve the effectiveness of the training intervention. MFIs need to consider educational qualifications and experience when selecting trainers and should give them opportunities to participate in TOT programmes. Further, trainers must be enlightened about the importance of using non-technical and motivational communication in training. Trainers must be encouraged to gain competency in different languages and communication tools. Moreover, they must be encouraged to use interactive learning and adult learning techniques in training. As the findings also reveal, the expertise of the trainer may be influenced the type of trainer (i.e. whether full-time, part-time, or client trainers), which in turn is largely determined by the type of MFI chosen for the study (i.e. public, bank, non-bank, NGO). As evidenced in MFI-1, it is better to have full time trainers who are highly competent and expertised. However, one also needs to think about the cost involved to maintain such a staff, which might be a factor as to why other MFIs opt to use part-time trainers. Nevertheless, MFIs using part-time trainers should give them proper training in order to improve their expertise. Further, MFIs which have client trainers need to provide more training to their staff as they were not as competent as the trainers in other MFIs. Therein, this study contributes to the knowledge domain of the business training of the microfinance sector. Future research can be done 
in the microfinance sector in other countries and in the small business sector in order to broaden the knowledge horizon.

\section{REFERENCES}

Abeysekera, R. (2016), "Enhancing entrepreneurship in Sri Lanka: the provision of business development services (BDS) by microfinance institutions to support the self-sufficiency of microenterprises" (Doctoral dissertation, Bournemouth University), available at: http://eprints.bournemouth.ac.uk/24721/ (Accessed 20 September 2019)

ACCION, 2005, Practical skills for micro entrepreneurs: ACCION's training with its ABC's of business training program, Boston: ACCION In Sight.

Agnew, N. M., Ford, K. M. and Hayes, J. P. (1997), "Expertise in context: personally constructed, socially selected, and reality-relevant?', in Feltovich, P. J., Ford, K. M. and Hoffman, R. R. (Eds), Expertise in Context, AAAI Press, Menlo Park, CA, pp. 219-244, available at: https://www.researchgate.net/publication/258857150_Expertise_Socially_Situated_Personally _Constructed_and_\%27Reality\%27_Relevant (Accessed 15 September 2019)

ADB, (1997), Microenterprise development: Not by credit alone. Manila: Asian Development Bank. https://www.findevgateway.org/library/microentreprise-development-not-credit-alone (Accessed 20 September 2019)

ADEMCOL, (2001), Asociacio'n para el Desarrollo Microempresarial Colombiano and Women's Opportunity Fund: Bundling microfinance and business development services, A case study from ADEMCOL in Colombia, Microenterprise Best Practices, Washington, DC: United States Agency for International Development.

Argote, L., McEvily, B. and Reagans, R. (2003), "Managing knowledge in organizations: an integrative framework and review of emerging themes", Management Science, Vol. 49 No. 4, pp. 571-82, available at: https://doi.org/10.1287/mnsc.49.4.571.14424 (Accessed 20 September 2019), DOI: $10.1287 / \mathrm{mnsc} .49 .4 .571 .14424$

Baldwin, T. T. and Ford, J. K. (1988), "Transfer of training: A review and directions for future research", Personnel Psychology, Vol. 41, Issue 1, pp. 63-105, available at: https://doi.org/10.1111/j.1744-6570.1988.tb00632.x (Accessed 15 September 2019), DOI: 10.1111/j.1744-6570.1988.tb00632.x

CGAP (2011), Advancing financial access to world poor [online], Washington: Consultative group to assist the poor, available at: https://www.cgap.org/ (Accessed 20 September 2019).

De Wildt, M. (2004), Linking business development services to financial services: The case of Financiera Solucio'n, Geneva: ILO, available at: https://www.ilo.org/empent/Publications/WCMS_143295/lang--en/index.htm (Accessed 10 September 2019).

Yamagata, T. (2006), The white man's burden: Why the West's efforts to aid the rest have done so much ill and so little good - by William Easterly, New York: Penguin Press, available at: https://doi.org/10.1111/j.1746-1049.2008.068_2.x (Accessed 10 September 2019), DOI: 10.1111/j.1746-1049.2008.068_2.x

Eisenhardt, K. M., (1989), "Building theories from case study research", Academy of management review, Vol. 14, No. 4, pp. 532-550, available at: https://doi.org/10.5465/amr.1989.4308385 (Accessed 10 September 2019), DOI: 10.5465/amr.1989.4308385

Gibb, A. A. (1997), "Small firms' training and competitiveness. Building Upon the Small business as a Learning Organisation", International small business journal: Researcing Entrepreneurship, Vol. 15, Issue 3, pp. 13-29, available at: https://doi.org/10.1177\%2F0266242697153001 (Accessed 15 September 2019), DOI: $10.1177 \% 2 \mathrm{~F} 0266242697153001$

GTZ ProMiS, (2010), Micro Finance Industry Report, Sri Lanka: GTZ ProMiS and the Banking 
Abeysekera, R. (2020), "Trainer expertise in business training: evidence from the Sri Lankan Microfinance Institutions", Management and entrepreneurship: trends of development, Vol. 2, Issue 12, pp. 8-21, available at: https://doi.org/10.26661/2522-1566/2020-2/12-01

With the Poor Network.

Henry, S. (2006), Good Practice in Business Development Services: How Do We Enhance Entrepreneurial Skills in MFI Clients? [Online], Toronto: Alterna Savings, available at: http://www.ruralfinanceandinvestment.org/node/59 (Accessed 15 September 2019).

Huber, B. (1999), "Experts in organizations: the power of expertise', Academy of business and administrative science conference, available at: https://pdfs.semanticscholar.org/9d2f/79399f7958e0d02caf55ef2891e23142dafc.pdf (Accessed 20 September 2019).

Hutchins, H. M. (2009), "In the trainer's voice : A study of training transfer practices", Performance improvement quarterly, Vol. 22, Issue 1, pp. 69-93, available at : https://doi.org/10.1002/piq.20046, (Accessed 15 September 2019), DOI: 10.1002/piq.20046

ILO (2002), Start and Improve Your Business linkages to finance program: The Zimbabwe case. project report, Harare: International Labour Office - SIYB Regional Project Office.

Karlan, D. and Valdivia, M. (2006), "Teaching Entrepreneurship: Impact of Business Training on Micro Finance Clients and Institutions", Economic Growth Centre Discussion Paper, No, 941, Yale University: Economic Growth Centre, available at: https://doi.org/10.1162/REST_a_00074 (Accessed 18 September 2019), DOI: 10.1162/REST_a_00074

Khavul, S., (2010), "Microfinance: Creating Opportunities for the Poor?", Academy of management perspectives, Vol. 24, No. 3, pp. 58-72, available at: https://doi.org/10.5465/amp.24.3.58 (Accessed 18 September 2019), DOI: 10.5465/amp.24.3.58

Manpower services commission (1975), Management training and the development in the small firm and the role of industrial training boards, Sheffield: Mimeograph.

Nieman, G. (2001), "Training entrepreneurs and small business enterprises in South Africa: a situational analysis", Education + Training, Vol. 43, No. 8/9, pp. 445-450, available at: https://doi.org/10.1108/00400910110411639 (Accessed 19 September 2019), DOI: $\underline{10.1108 / 00400910110411639}$

Nonaka, I. (1998), “The knowledge-creating company", The Economic Impact of Knowledge, pp. 175-187, available at: $\mathrm{http}: / / \mathrm{dx}$.doi.org/10.1016/b978-0-7506-7009-8.50016-1 (Accessed 19 September 2019), DOI: 10.1016/b978-0-7506-7009-8.50016-1

Sié, L. and Yakhlef, A. (2009), "Passion and expertise knowledge transfer", Journal of Knowledge Management, Vol. 13, No. 4, pp. 175-186, available at: https://doi.org/10.1108/13673270910971914 (Accessed 20 September 2019), DOI: 10.1108/13673270910971914

Sievers, M. and Vandenberg, P. (2007), "Synergies through linkages: who benefits from linking micro-finance and business development services?", World development, Vol. 35, Issue 8, pp. 1341-1358, available at: https://doi.org/10.1016/j.worlddev.2007.04.002 (Accessed 20 September 2019), DOI: 10.1016/j.worlddev.2007.04.002

Tilakaratne, G., Wickramsinghe, U. and Thusitha, K., (2005), Micro finance in Sri Lanka: a household level analysis of outreach and impact on poverty, Sri Lanka: Institute of Policy Studies of Sri Lanka, available at: http://www.pep-net.org/sites/pepnet.org/files/typo3doc/pdf/files_events/4th_colombo/Ganga.pdf (Accessed 10 September 2019).

Tilakaratne, G., Galappattige, A. and Perera R. (2009), Promoting empowerment through microfinance in Sri Lanka, Economic and political empowerment of the poor - Sri Lanka, Sri Lanka: Centre for policy dialogue, South Asia Centre for policy studies.

TJP (2003), TkwinJdid Performance Report, March - December 2002, and Final Report, Implementation Grant Program, United States Agency for International Development.

Walker, E., Redmond, J., Webster, B. and Le Clus, M. (2007), "Small business owners: too busy to train?", Journal of small business and enterprise development, Vol. 14, No. 2, pp. 294-306, 
available at: https://doi.org/10.1108/14626000710746718 (Accessed 20 September 2019), DOI: https://doi.org/10.1108/14626000710746718

World Bank (2014), Poverty Review [Online], Washington DC: World Bank, available at: http://www.worldbank.org/en/topic/poverty/overview (Accessed 18 May 2020).

Yin, R. K. (2009), Case-study research: Design and methods, 4th ed., London: Sage.

Zorn T. E. Jr. and Ruccio, S. E. (1998), "The use of communication to motivate college sales teams", International Journal of Business Communication, Vol. 35, Issue 4, pp. 468-499, available at: https://doi.org/10.1177\%2F002194369803500403 (Accessed 25 September 2019), DOI: $10.1177 \% 2 F 002194369803500403$

\title{
ДОСЛІДЖЕННЯ ДОСВІДУ ІНСТРУКТОРІВ БІЗНЕС-ТРЕНІНГІВ: ДАНІ МІКРОФІНАНСОВИХ ОРГАНІЗАЦІЙ ШРІ-ЛАНКИ
}

\author{
Ruwan Abeysekera \\ Університет Келані, Шрі-Ланка
}

Мікрофінансові організації (МФО) проводять бізнес-тренінги для своїх клієнтів 3 метою поліпшення їх знань і навичок, щоб вони могли ефективно і результативно керувати своїм бізнесом. У МФО також можуть бути більш високі показники погашення кредитів за рахунок навчання бізнесу. Таким чином, бізнес-тренінг важливий як для МФО, так і для клієнтів. Для успішного проведення бізнес-тренінгів досвід інструкторів має велике значення. Отже, цілі цього дослідження полягають у тому, щоб визначити експертні знання, визначити, як експертні знання можуть допомогти клієнтам у їх ділових починаннях i визначити стратегії, використовувані інструкторами для передачі своїх експертних знань. Метод тематичного дослідження був використаний для проведення цього дослідження, i шість МФО Шрі-Ланки були використані в якості прикладів. Один менеджер, один тренер і один власник-менеджер / клієнт від кожної МФО були відібрані для інтерв'ю, i, отже, було проведено 18 глибоких інтерв'ю для збору даних. Результати показують, що досвід інструкторів складається 3 бізнес-знань i досвіду безпосередньо. Інструктори використовують бізнес-знання для надання предметних знань, таких як фінансова грамотність та підготовка бізнес-плану. Досвідчені знання використовуються для створення мережевих можливостей, а також для надання предметних знань. Крім того, інструктори використовують такі стратегії, як інтерактивне навчання та спілкування для передачі досвіду. Результати цього дослідження були б корисні для практиків мікрофінансування, політиків, а також є внеском до галузі знань мікрофінансування.

Ключові слова: бізнес-тренінг, мікрофінансування, інструктори, досвід, мікропідприємства.

\section{ИССЛЕДОВАНИЕ ОПЫТА ИНСТРУКТОРОВ БИЗНЕС-ТРЕНИНГОВ: ДАННЫЕ МИКРОФИНАНСОВЫХ ОРГАНИЗАЦИЙ ШРИ-ЛАНКИ}

\author{
Ruwan Abeysekera \\ Университет Келания, Шри-Ланка
}

Микрофинансовые организации (МФО) проводят бизнес-тренинги для своих клиентов с целью улучшения их знаний и навыков, чтобы они могли эффективно и результативно управлять своим бизнесом. У МФО также могут быть более высокие показатели погашения кредитов за счет обучения бизнесу. Таким образом, бизнес-тренинг важен как для МФО, так и для клиентов. Для успешного проведения бизнес-тренингов опыт инструкторов имеет большое значение. Следовательно, цели этого исследования состоят в том, чтобы определить 
Abeysekera, R. (2020), "Trainer expertise in business training: evidence from the Sri Lankan Microfinance Institutions", Management and entrepreneurship: trends of development, Vol. 2, Issue 12, pp. 8-21, available at: https://doi.org/10.26661/2522-1566/2020-2/12-01

экспертные знания, определить, как экспертные знания могут помочь клиентам в их деловых начинаниях и определить стратегии, используемые инструкторами для передачи своих экспертных знаний. Метод тематического исследования был использован для проведения этого исследования, и шесть МФО Шри-Ланки были использованы в качестве примеров. Один менеджер, один тренер и один владелец-менеджер / клиент от каждой МФО были отобраны для интервью, и, следовательно, было проведено 18 глубоких интервью для сбора данных. Результаты показывают, что опыт инструкторов состоит из бизнес-знаний и опыта. Инструкторы используют бизнес-знания для предоставления предметных знаний, таких как финансовая грамотность и подготовка бизнес-плана. Опытные знания используются для создания сетевых возможностей, а также для предоставления предметных знаний. Кроме того, инструкторы используют такие стратегии, как интерактивное обучение и общение, для передачи опыта. Результаты этого исследования были бы полезны для практиков микрофинансирования, политиков, в также вносят вклад в область знаний микрофинансирования.

Ключевые слова: бизнес-тренинг, микрофинансирование, инструкторы, опыт, микропредприятие. 